\title{
GENDER AND INNOVATION IN THE COUNTRIES OF THE BALTIC SEA REGION
}

\author{
Marta Hozer-Koćmiel*, Sandra Misiak-Kwit**, Ewa Lisowska***, \\ Ewa Rumińska-Zimny****
}

\begin{abstract}
Background. Innovation has not only become a common theme in academic research but it also tops public debates and policy agendas worldwide.
\end{abstract}

Research aims. The paper takes a theoretical and practical approach to innovation in women-led small and medium-sized enterprises (SMEs). It consists of two parts. In the first part we provide a critical review of the literature on gender and innovation, pointing out that the gender dimension is not taken into consideration. It this context we attempt to provide a gender-sensitive definition of innovation and its policy implications. In the second part we present the results of a pilot survey on women-led SMEs in Baltic Sea countries.

Methodology. The survey's questions permitted to analyse motives for, and barriers to start own SME by women in creative industries and tourism, as well as the scope of innovations in their businesses and the availability of the financial and institutional support at national and local levels. It was conducted in 2015 among 102 women owners of firms in Estonia, Latvia, Lithuania, Poland and Sweden.

Key findings. The main conclusion is that women's economic and innovative potential remains untapped in all countries which that companiec representing the sector of creative industries/services are more innovative than companies representing the tourism sector. The paper is part of the project: Thematic Partnership Winnet Baltic Sea Region Winnet BSR "Gender, Innovation and Sustainable Development in the Baltic Sea Region (BSR)", financed by the Swedish Institute in 2013-2016 (www.balticsearegion.org/web/).

Keywords: innovation, innovativeness, women, gender, entrepreneurship, Baltic Sea Region.

*University of Szczecin. E-mail: mhk@wneiz.pl

** University of Szczecin. E-mail: s.misiak@wneiz.pl

**** Warsaw School of Economics. E-mail: ewael@sgh.waw.pl

***** Międzynarodowe Forum Kobiet, Gender Studies IBL PAN. E-mail: ewa.ruminska-zimny@ mfk.org.pl 


\section{INTRODUCTION}

Innovation has not only become a common theme in academic research, but it also tops public debates and policy agendas worldwide. In Europe, promotion of innovation is one of the five strategic goals of Europe 2020, supported with 80 billion euro funding in the framework of Horizon 2020 (https://ec.europa.eu/research/participants/portal/desktop/en/ opportunities/). There is no doubt that innovation has moved to the centre of a new paradigm redefining growth and development. If successful, it can become a driving force of any economy, reshaping the entire industries and stimulating inclusive and sustainable growth (OECD Forum, 2014). In order to be effective, it requires investments in knowledge and human and social capital, as opposed to natural resources- and industrialisation-based growth and development, known from the past. In this context, the key issue is to mobilise the innovative potential of both men and women. The discourse in this area, however, is characterised by a clear gender bias: women are disregarded as innovators.

This could be explained by the traditional definition of innovation in terms of developing new technologies, materials, and methods of production. The last mentioned required knowledge in STEM (science, technology, engineering, and mathematics), an education profile typical for men as opposed to art, humanities, and social sciences typical for women. As a result innovation strategies at company and/ or country level, funding and research priorities focused on technology and male-dominated sectors. The way innovation has been defined, and perceived at policy levels, left behind innovation in services and female dominated-sectors (e.g., public services, culture). It also made it difficult (if not impossible) to mainstream gender into innovative research and policies as both are constrained by a male-labelled concept (Nählinder et al., 2012, p. 351).

Beyond conceptual issues, the lack of a gender perspective in research is related to the methodology and framework of analysing innovation. Research is concentrated on the process, its effectiveness, and results and not on individual innovators or people behind this process (Alsos et al., 2013). This contrasts, for example, with the research on entrepreneurship, which focuses on business owners, and investigates motives, barriers, or the propensity of individuals to being 
entrepreneurial, which allows to include male and female perspectives (Rumińska-Zimny, 2004).

It should be noted, however, that there have been some positive changes over the last years in terms of the ways innovation is defined and the development of a new research area on gender and innovation. Innovation is not restricted anymore to technical aspects, but refers also to "soft" issues such as ideas, design, or management. There is a number of studies providing arguments why and how the innovation area could open to a gender perspective both in research and policies. The Swedish innovation agency VINNOVA, played a pioneering role in this area (Danilda \& Thorslund, 2011).

A recent VINNOVA report summarises research done over the last ten years (Andersson et al., 2012). It points, among others, to the role of innovation in feminised sectors, such as public services. It pays attention to social innovation, the link between innovation and female entrepreneurship, as well as to the importance of creative industries, which are at the crossroads between arts, business, and technology. These industries heavily rely on intellectual property, but they also have their origin in individual creativity.

The development of creative industries strengthens the case for gender equality in innovation and allows for using their potential in human sciences (feminised area of education) and talents in arts, crafts, marketing, or social science or crafts, which are all part of creative industries (Dodd, 2012; Niemczewska et al., 2007). The pilot survey of women led SMEs presented in the second part of the paper analyses this potential in creative industries as compared to tourism in five BSR countries (Estonia, Latvia, Lithuania, Poland, and Sweden). The aim of the article is to describe the innovative potential of women-led small and medium-sized enterprises in the chosen Baltic Sea Region countries.

\section{LITERATURE REVIEW}

The concept of innovation has changed over the years. In the past, innovation was associated only with large corporations and emanated primarily or exclusively from research and development (R\&D) laboratories or departments. Nowadays, a broader view of innovation has emerged. The basic definition says that innovation "refers to new 
ideas, new knowledge, and new technologies and design" (Gendered Innovations, 2013, p. 11).

In the third edition of the Oslo Manual the definition of innovation was extended in several important ways (Oslo Manual, 2005):

a) by placing greater emphasis on the symbiotic nature of innovation, emphasising the role of linkages among players in the innovation process;

b) by recognising that innovation can and does occur in less R\&D-intensive sectors;

c) by expanding the definition of innovation beyond that which is found in products and processes to also include innovative practices in organisational behaviour and in marketing.

Based on this, the meaning of innovation has got a new form as the implementation of a new or significantly improved product (good or service), or process, a new marketing method, or a new organisational method in business practices, workplace organisation or external relations. This definition of innovation extends beyond products and processes and includes organisational behaviours and marketing, as well as any innovative practice new to an already existing company.

Despite the fact that most definitions do not include a gender aspect, there are some exceptions. The most common definition of Gendered Innovations describe it as "processes that integrate sex and gender analysis into all phases of basic and applied research to assure excellence and quality in outcomes" (Gendered Innovations, 2013, p. 11). This meaning of innovation has been stressed by the European Commission by establishing a group called "Innovation Through Gender." The goal of this group of experts is to conduct a many-sided review of this field, but also to prepare techniques for gender analysis. The main thesis is that gender differences should be treated appropriate, what can enhance research.

It is important to include the gender aspect to the definition of innovation, because it will add value to society, research, engineering, and business. Creating added value is possible by:

a) "ensuring excellence and quality in outcomes and enhancing sustainability.

b) making research more responsive to social needs.

c) developing new ideas, patents, and technology" (Gendered Innovations, 2013, p. 7). 
Support for gender equality can be created by defining a pathway that connects empowerment and innovation [Malhotra et al., 2009, pp. 4-5). An example of such a pathway, that consist of five dynamic areas, has been presented in the Figure 1 .

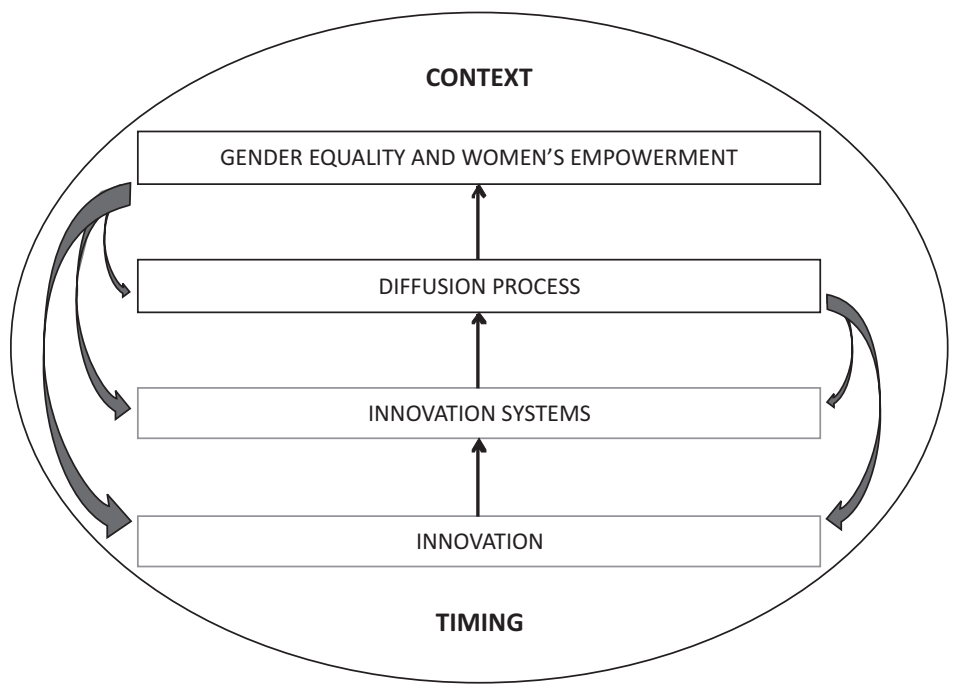

Figure 1. Gender equality vs. innovation

Source: own compilation based on: Malhotra et al., 2009, p. 4.

To identify the scope of research related to gender and innovation, several searches were undertaken. The studies of Scopus database papers have shown that males are more likely than females to engage in industry cooperation. The relationship between gender and involvement in industry innovation is complex and it includes the intersection of gender and family responsibilities that impede women's ability to innovate (Alsos et al., 2013, pp. 236-256; Lewis, 2006; Brush et al., 2009, pp. 8-24).

In general perceptions of gender in society there is a strong association of innovation and technology with masculinity, and women are seen as less innovative than men (Wajcman, 2010). Innovation activity is often connected mainly with high-technology and manufacturing industries since these industries represent the fields where innovation occurs (Lindberg et al., 2014, pp. 94-113). The role models presented in mass media have also a great influence on this situation. Women, who are more likely to be found in other sectors than high-technology and manufacturing industries, may feel estranged to the concept and stereotypes of entrepreneurship. 
It should be stressed that gender differences include important differences in needs, behaviours and attitudes and taking them into account provides new, relevant for whole society, ideas and excellence during conducting research (Gendered Innovations, 2013, p. 7). In BSR countries the social aspect of women's entrepreneurship is also important. For small and medium sized enterprises in this region, corporate social responsibility is the key to future success and does not need to be very costly. It helps to conquer barriers which hinder women from starting their own business and develop a strategy to change this. Women entrepreneurship has an unrecognised potential which may occur or be realised by improving women's ability to access education, health care system, earning opportunities, socio-political rights, and women entrepreneurship. It is important to consider women potential activity, but also opportunities and barriers according to young women as a corporate leader and the problem of self-employment in the female population in BSR (Hogeforster \& Jarke, 2013).

\section{MOTIVATIONS AND BARRIERS DECLARED BY FEMALE ENTREPRENEURS IN THE BALTIC SEA REGION}

The analysis concerns motivations and barriers which were identified on the basis of a test questionnaire survey, carried out in the second half of 2015 in the five countries: Estonia, Poland, Sweden, Lithuania, and Latvia. The survey was carried out on a sample selected in a purposeful way via the questionnaire interview method. It was a qualitative survey: in each of the five countries the interviews were carried out with women who had been conducting their own businesses for at least 3 years in tourism sector (10 women) and creative industries/services sector - ICT (10 women). The selection of women for the survey was done through local business organisations; the interviewers were female students, employees of a university or business organisation. Overall, 102 interviews were completed: in Sweden, Estonia and Lithuania 20 in each country, and in Poland and Latvia - 21 in each country. The survey included women conducting economic activity within the scope of tourism (tourist agencies; tourist services; accommodation; tourist transport) and creative industries/services (UNCTAD, 2010, p. 7; Hesmondhalgh, 2002: pp. 11-12; Howkins, 2001, p. 8), such as software and computer services; film, television and video production; 
computer games; music; visual arts; advertising; architecture; designing; engineering.

\section{Motivations}

On the ground of psychology it is assumed that motivation is something that stimulates and encourages into action (Stevenson, 2002, p. 2). The source of motivations are the needs (Gibson et al., 1988, p. 127; Pocztowski, 2008, p. 205). Among the motivation theories drive theories and incentive theories may be specified: the former indicate the significance of internal factors for stimulating an individual into undertaking activities, while the latter point out to external factors (Carsrud \& Brännback, 2011, p. 11).

Regarding the results of the survey carried out among women entrepreneurs in the Baltic Sea countries, it may be concluded that the major factors motivating women to taking up self-employment comprise individual traits and aspiration to utilise their own potential in a better way than in case of traditional employment relation (paid work), which not always offers a chance for promotion and high earnings. These factors draw to business and they were also identified in other surveys (Lisowska, 2001, pp. 72-73; Grzegorzewska-Mischka, 2010 , pp. 52-53). As the same kind of factors may also be considered the support of a husband or partner, which is particularly important in case of women due to the stereotypes about lower entrepreneurial predispositions of women. Possibility to obtain financial means for starting an economic activity and institutional support (training and subsidies offered by local employment offices; easy access to care institutions) constitute successive factors encouraging (drawing to) launching one's own company. On the other side are factors, such as difficulties with finding a job caused by high unemployment or lack of possibilities for promotion in paid work.

Figure 2 presents the factors motivating women to setting up their own businesses divided into push and pull, as the percentage of the total of the declared motives. It may be seen, that pull factors were pointed out relatively more often than push factors, which means that decisions regarding setting up their own business made by the surveyed women were rather a matter of their own choice than necessity. According to other surveys (Lisowska, 2001; Hughes, 2003; Orhan 2005), the motivations of women for launching their own businesses are similar 
to the motivations of men entrepreneurs, among whom pull factors are also dominant. In case of women entrepreneurs, slightly more often than in case of men, push factors are in force.

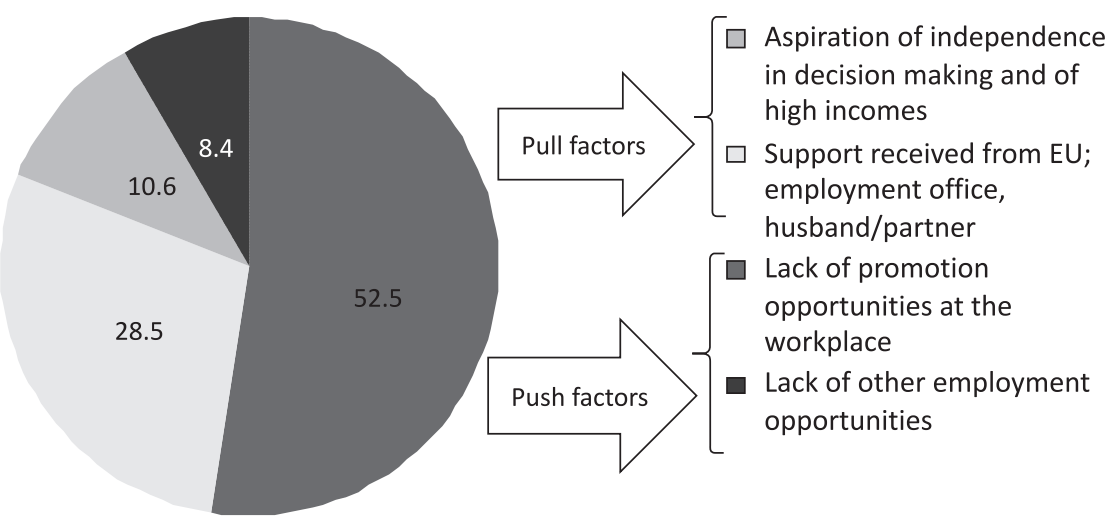

Figure 2. Motivations of women entrepreneurs to start their own business (\%) Source: results of the survey carried out by authors in 2015 within the project Gender, Innovation, and Sustainable Development in the Baltic Sea Region.

\section{Barriers to women's entrepreneurship}

Barriers to entrepreneurship identified in the previous surveys (Lisowska, 1997, 2004; PARP, 2011; Misiak, 2014a, pp. 311-320) comprise mainly obstacles of an economic nature, i.e. high taxes, problems with acquiring new customers, access to capital, as well as barriers of an administrative character - long or strenuous administrative procedures and complicated tax laws. Other significant barriers constitute access to knowledge and training, i.e. education in the field of entrepreneurship, including education at the higher level. In case of women, a significant role is played by barriers of a cultural nature (Hisrich \& Brush, 1984; Lisowska, 2004; GEM, 2012). Positive perception of personal abilities and skills, as well as chances for success is much higher in case of men, whereas the fear of failure is evidently higher among women. Therefore, it is more difficult for women than for men to make decisions regarding initiation of self-employment. Nevertheless, socio-cultural determinants are also perceived at the phase of maintaining one's own company and its development: female company owners signalise problems with combining work and family responsibilities due to limited access to institutional childcare (Lisowska, 2014). 
Table 1. Barriers declared by women entrepreneurs in BSR (the number of "yes" and "probably yes" answers)

\begin{tabular}{|l|c|c|c|c|c|c|}
\hline \multicolumn{1}{|c|}{ Barriers } & Estonia & Lithuania & Latvia & Poland & Sweden & $\begin{array}{c}\text { Total in \% } \\
\text { (N = 102) }\end{array}$ \\
\hline High taxes & 17 & 18 & 20 & 18 & 17 & 88.2 \\
\hline Complicated tax laws & 10 & 18 & 12 & 12 & 15 & 65.7 \\
\hline $\begin{array}{l}\text { Long administrative } \\
\text { procedures }\end{array}$ & 7 & 14 & 13 & 13 & 12 & 57.8 \\
\hline $\begin{array}{l}\text { High costs of managerial } \\
\text { trainings }\end{array}$ & 14 & 7 & 5 & 11 & 9 & 45.1 \\
\hline $\begin{array}{l}\text { Difficulties in combining } \\
\text { work with caring for a } \\
\text { child / elderly person }\end{array}$ & 5 & 4 & 4 & 10 & 3 & 25.5 \\
\hline Lack of belief in success & 1 & 3 & 3 & 1 & 2 & 9.8 \\
\hline
\end{tabular}

Source: results of the survey carried out by authors in 2015 within the project Gender, Innovation, and Sustainable Development in the Baltic Sea Region.

The data included in Table 1 confirm that in the Baltic Sea countries barriers to women's entrepreneurship are mostly of economic (high taxes) and administrative (complicated tax law and long administrative procedures) nature. Almost a half of the surveyed women entrepreneurs indicated an obstacle in a form of high costs of managerial training. This barrier is most often reported by women from Estonia and Poland, while it was the least frequently declared by women from Latvia. Socio-cultural barriers were declared by more than one/third of the surveyed women, including difficulties in combining work with caring duties - by $26 \%$. These barriers are most often declared by women entrepreneurs from Poland, while the least often - by women from Sweden. It is worth to add that while economic and administrative barriers are perceived by all entrepreneurs (Grzegorzewska-Mischka, 2010 , p. 80), the socio-cultural ones concern only women and they are the most significant at the stage of making a decision regarding setting up one's own company (Lisowska, 2004, pp. 56-57).

\section{FINANCIAL AND INSTITUTIONAL SUPPORT FOR WOMEN IN THE BALTIC SEA COUNTRIES}

The majority of the surveyed entrepreneurs indicated that in their countries women may obtain support at the start of their own company; a distinctive country here is Sweden, where almost all (19 
per 20 surveyed) women entrepreneurs agreed with this statement. Slightly over a half of women agreed that the country's socio-economic situation facilitates launching businesses by women - it was the most often stated by Estonian and Latvian women, while the least often by women from Lithuania and Sweden (see Figure 3).

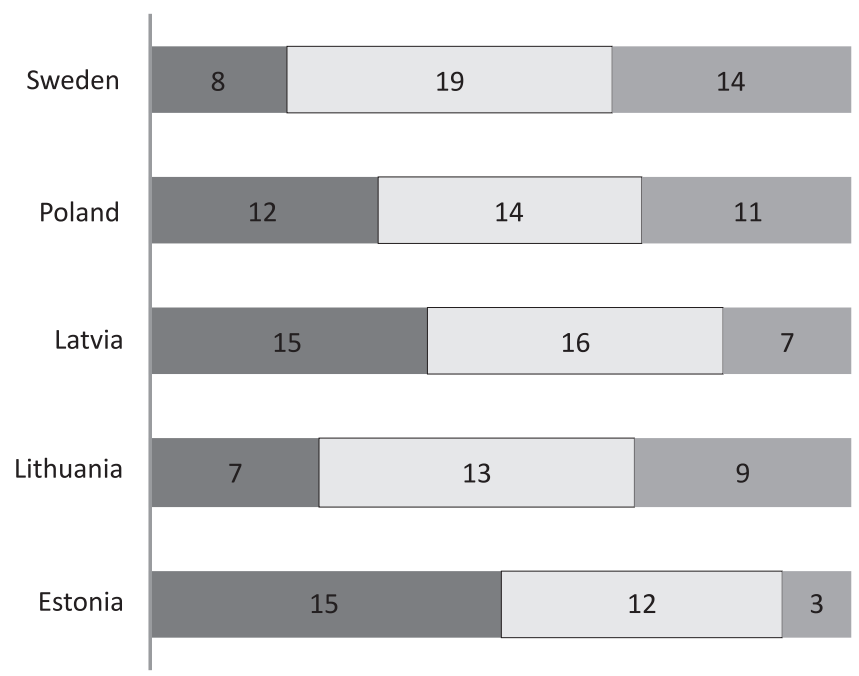
Socio-economic situation in my country is favourable for female entrepreneurship
$\square$ Women in my country have possibilities to receive support in starting own business
Women in my country are discriminated against on the labour market

Figure 3. Women entrepreneurs by the assessment of the situation of women in each country (the number of 'yes' and 'probably yes' answers)

Source: results of the survey carried out by authors in 2015 within the project Gender, Innovation, and Sustainable Development in the Baltic Sea Region.

An interesting picture presents the respondents' reaction to the statement: "women in my country are discriminated against on the labour market." Overall, 43\% agreed with this statement. In Sweden, which holds the top position in the Gender Equality Index (EIGE, 2013) ranking, women entrepreneurs most often indicated the phenomenon of discrimination against women on the labour market (14 respondents per 20 surveyed women), while women from Estonia - the least often (3 respondents per 20 surveyed women). These data indicate rather the awareness of the phenomenon of discrimination against women on the labour market, which is the highest in Sweden, than the actual scope of discrimination against women.

Almost $1 / 3$ of the total of the surveyed women complained about the lack of financial support and professional advice for women from the government or local institutions. Whereas the lack of financial 
support was declared with similar intensity in particular countries of the Baltic Sea Region, lack of counseling support was the least often declared in Sweden (only by two women entrepreneurs), while the most often in Poland (10 women) and Estonia (9 women) - see Figure 4.

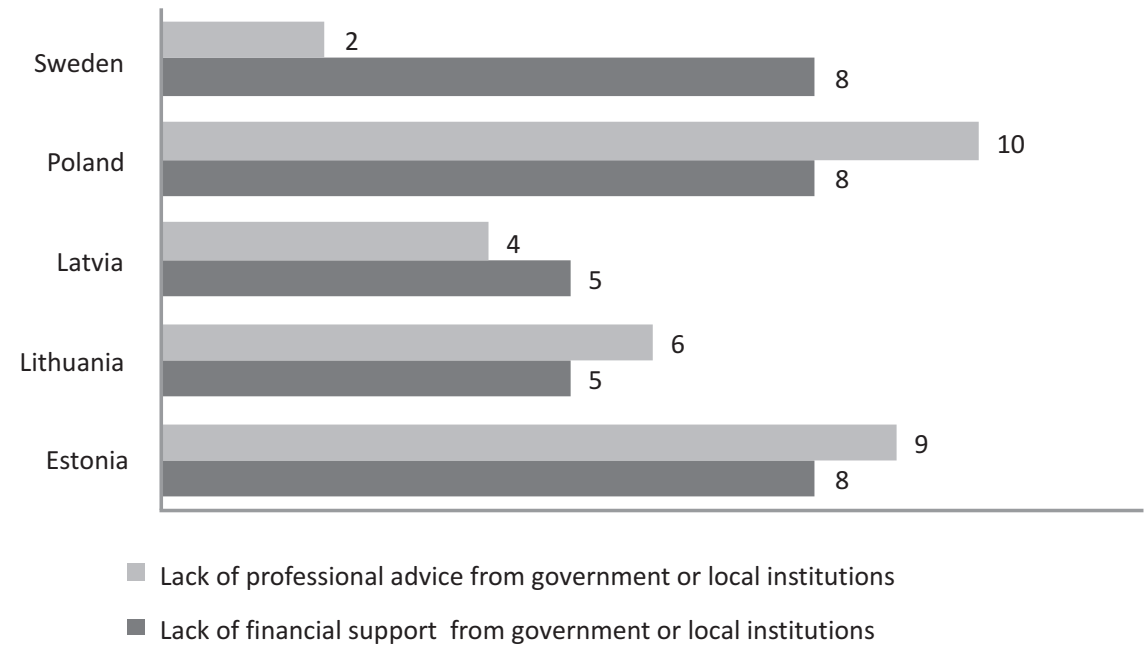

Figure 4. Women entrepreneurs by assessment of the financial and advice support from government or local institutions (the number of 'yes' and 'probably yes' answers)

Source: results of the survey carried out by authors in 2015 within the project Gender, Innovation, and Sustainable Development in the Baltic Sea Region.

In the opinion of the surveyed entrepreneurs, at the stage of setting up own business, support and reliable information may be obtained mainly from family or friends, then from an advisory-accountant firms. Regarding the mentioned issues, employment offices and local authorities got worse assessment, female non-governmental organisations were evaluated even lower. At the same time in case of these three institutions often the given answer was "difficult to say."

\section{INNOVATIONS AND THEIR TYPES}

For the purpose of the survey among women entrepreneurs in BSR, a broad definition of innovation was applied, thus each new and qualitatively different action or solution which leads to better satisfaction of 
customers' needs both the previous, as well as the new ones (Drucker, 1992, pp. 42-44; Dobiegała-Korona, 2003, p. 284). Therefore, it was assumed that innovation is not only launching a new product/service into the market or implementation of a new technological process, but also improvements related to marketing or human resources management (UNCTAD, 2010).

In each of the countries, the surveyed female company owners declared, that in the period 2011-2014 they adopted some innovative solutions. Relatively the highest number of innovations was implemented by women from Poland, while women from Sweden implemented the fewest innovations. It is possible that the explanation lies in the non-random sample of women entrepreneurs. In case of Sweden they were the most often marketing innovations, in Poland - product and marketing innovations, while in other countries - both marketing, as well as the product and process ones. The least often were organisational innovations (see Figure 5). Based on the results, we cannot explain why Swedish women's innovation activity is the lowest when compare to women's innovation in other countries.

Companies of creative industries/services sector implemented more innovations than firms of the tourism sector. Marketing and process innovations were evidently more numerous in the sector of creative industries/services than in the tourism sector. The obtained results allow for a conclusion that companies from the sector of creative industries/ services are more innovative than tourist companies. At the same time, the enterprises of this sector are characterised by higher participation of not only marketing innovations, but also the process and product ones.

Previous surveys identified that innovations implemented by self-employed women related mainly to broadening the range of products and services, as well as the organisation of work. Even minor changes, implemented regularly, not only improve the functioning of the company, but also support their development. Development plans reflect the potential for innovation, where $74 \%$ of surveyed women intent to implement new products and/or services, $65 \%$ plan to purchase new equipment, machinery, and technology and $64 \%$ set on entry into new markets and/or an increase in employment. The surveyed self-employed women in Poland, which have development plans, are characterised by the same features - entrepreneurial attitude, self-satisfaction and applying for funding while establishing an own company (Misiak, 2014b, pp. 149-158). 


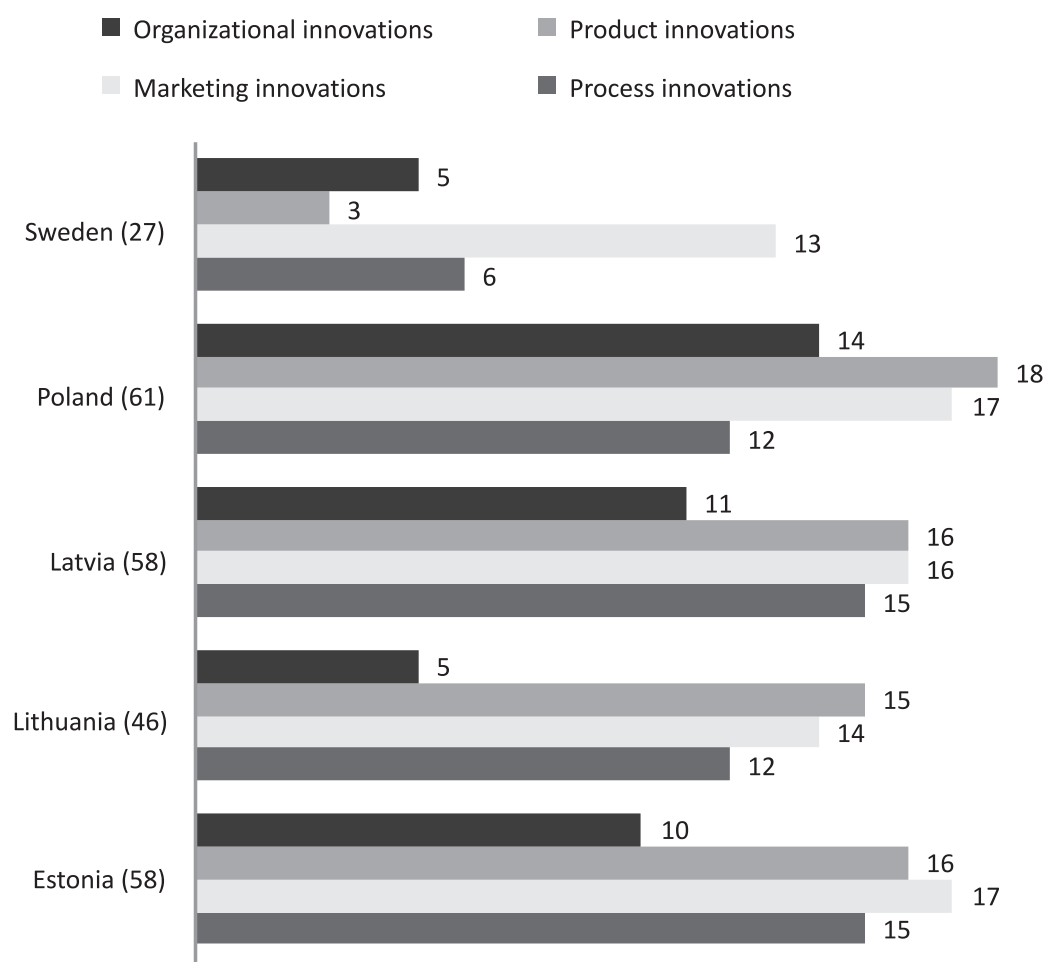

Figure 5. Number and kind of innovations introduced by women entrepreneurs in BSR countries in 2011-2014

Source: results of the survey carried out by authors in 2015 within the project Gender, Innovation, and Sustainable Development in the Baltic Sea Region.

\section{CONCLUSIONS}

Clearly, women's economic and innovative potential remains untapped in all countries which were analysed. However, there is at least one positive conclusion from the pilot survey: the main factors motivating women for undertaking self-employment in the Baltic Sea countries are pull factors, i.e. desire to utilise own potential and obtain high income. Push factors (difficulties with finding a job or reentering the labour market after the break caused by childcare, glass ceiling) were declared less often.

Barriers usually comprise high taxes, complicated tax law, and long administrative procedures. Another significant barrier to women's entrepreneurship is constituted by high costs of managerial training, 
which may indicate difficulties with access to education in the field of entrepreneurship. Characteristic for women are socio-cultural barriers, and among them access to childcare institutions: these barriers were most often declared by women entrepreneurs from Poland, while the least often they are pointed out by the women from Sweden. The differences in this field are caused by the different legal and economic status of each country.

Due to socio-cultural barriers and discrimination against women on the labour market, very important is the support from government or local institutions to women who want to set up their own business. This support is relatively most advanced in Sweden, particularly regarding business counselling. Nevertheless, in all countries the main source of information and support are family or friends.

The obtained data imply that companies representing the sector of creative industries/services are more innovative than companies representing the tourism sector. In both sectors innovations concerned mainly marketing, and then products or services, while the least often organisational processes.

The results of the survey outlined the situation of women entrepreneurs and indicated its differentiation in the Baltic Sea countries. It should be underlined that the sample was not representative and the conclusions are not strong enough - they are formulated as hypotheses for further research carrying out on the larger samples of women company owners. Carrying out research on larger samples of women company owners is justified in order to validate the conclusions drawn on the basis of the test survey. For comparison purposes the future survey should also include men.

\section{REFERENCES}

Alsos, G.A., Ljunggren, E. \& Hytti, U. (2013). Gender and innovation: state of the arts and a research agenda. International Journal of Gender and Entrepreneurship, 5(3), 236-256.

Andersson, S., Berglund, K., Gunnarsson, E. \& Sundine, E. (eds.) (2012). Promoting Innovation: Policies, Practices and Procedures. Stockholm: Vinnova Report VR 2012:08.

Brush, C.G., de Bruin, A. \& Welter, F. (2009). A gender-aware framework for women's entrepreneurship. International Journal of Gender and Entrepreneurship, 1(1), 8-24. 
Carsrud, A. \& Brännback, M. (2011). Entrepreneurial Motivations: What Do We Still Need to Know? Journal of Small Business Management, 49(1), 9-26. Danilda, I. \& Thorslund, G. (eds.) (2011). Innovation and Gender. Stockholm: Vinnova Information VI 2011:03. [Online] Retrieved from: http://www.vinnova.se/ upload/EPiStorePDF/vi-11-03.pdf.

Dobiegała-Korona, B. (2003). Innowacje a zarządzanie wiedzą o kliencie. In: H. Brdulak, T. Gołębiowski (eds.), Wspólna Europa: innowacyjność w działalności przedsiębiorstw. Warszawa: Difin.

Dodd, F. (2012). Women leaders in the creative industries: a baseline study. International Journal of Gender and Entrepreneurship, 4(2), 153-178.

Drucker, P.F. (1992). Innowacja i przedsiębiorczość. Warszawa: PWE.

EIGE. (2013). Gender Equality Index - Country Profiles. Vilnius: European Institute for Gender Equality.

Gendered Innovations (2013). How Gendered Analysis Contributes To Research, Report of the Expert Group "Innovation through Gender". Luxemburg: European Commission.

GEM (2012). Global Entrepreneurship Monitor: Poland. Warszawa: Polish Agency of Entrepreneurship Development and University of Economics in Katowice. Gibson, J.L., Ivancevich, J.M. \& Donnelly, J.H. (1988). Organizations: Behavior, Structure, Processes. Texas, Plano: Business Publications.

Grzegorzewska-Mischka, E. (2010). Wspótczesne uwarunkowania rozwoju przedsiębiorczości w Polsce. Warszawa: Szkoła Główna Handlowa w Warszawie. Hesmondhalgh, D. (2002). The Cultural Industries. London: Sage.

Hisrich, R.D. \& Brush, C.G. (1984). The Woman Entrepreneur: Management Skills and Business Problems. Journal of Small Business Management, 22(1), 30-37.

Hogeforster. M. \& Jarke, P. (eds.) (2013). Corporate Social Responsibility and Women's Entrepreneurship around the Mare Balticum. Germany: Baltic Sea Academy. Howkins, J. (2001). The Creative Economy: How People Make Money From Ideas. USA: Penguin Group Incorporated.

Hughes, K.D. (2003). Pushed or Pulled? Women's Entry into Self-Employment and Small Business Ownership. Gender, Work \& Organization, 10(4), 433-454.

Lewis, P. (2006). The Quest for Invisibility: Female Entrepreneurs and the Masculine Norm of Entrepreneurship. Gender, Work and Organization, 5(5), 453-469.

Lindberg, M., Lindgren, M. \& Packendorff, J. (2014). Quadruple Helix as a Way to Bridge the Gender Gap in Entrepreneurship: The Case of an Innovation System Project in the Baltic Sea Region. Journal of the Knowledge Economy, 5(1), 94-113. 
Lisowska. E. (1997). Women's participation in SME sector development: motivation and barriers. In: E. Masłyk-Musiał \& E. Lisowska (eds.), Polish Women in the Business World. Lublin: Marie Curie-Skłodowska University Press.

Lisowska, E. (2001). Przedsiębiorczość kobiet w Polsce na tle krajów Europy Środkowej $i$ Wschodniej. Monografie i Opracowania, nr 494. Warszawa: SGH.

Lisowska, E. (2004). Business initiative of Polish women. In: Gender and Economic Opportunities in Poland: Has Transition Left Women Behind? Warsaw: World Bank.

Lisowska, E. (2014). Self-employment and motherhood: the case of Poland. In: K.V. Lewis, C. Henry, E.J. Gatewood \& J. Watson (eds.), Women's Entrepreneurship in the 21st Century. An International Multi-Level Research Analysis. UK: Edward Elgar, Cheltenham, USA: Northampton.

Malhotra, A., Schulte, J., Patel, P. \& Petesch P. (2009). Innovation for Women's Empowerment and Gender Equality. Washington D.C.: The International Center for Research on Women.

Misiak, S. (2014a). Bariery rozwoju małych firm prowadzonych w Polsce przez kobiety. In: P. Wachowiak \& S. Winch (eds.), Granice w zarzadzaniu kapitatem ludzkim. Warszawa: Szkoła Główna Handlowa w Warszawie.

Misiak, S. (2014b). Innowacje wprowadzane przez samozatrudnione kobiety w Polsce - studium przypadków. Zeszyty Naukowe Małopolskiej Wyższej Szkoły Ekonomicznej w Tarnowie, 24(1), 149-158.

Nählinder, J., Tillmar, M. \& Wigren-Kristoferson, C. (2012). Are Female and Male Entrepreneurs equally Innovative? In: S. Andersson, K. Berglund, E. Gunnarsson \& E. Sundin (eds.), Promoting Innovation: Policies, Practices and Procedures. Stockholm: Vinnova Report VR 2012:08.

Niemczewska, M., Mrowiec, K. \& Paterek, A. (2007). Rola kobiet w innowacyjnej przedsiębiorczości wysokich technologii. Warszawa: PARP.

Orhan, M. (2005). Why women enter into small business ownership. In: S.L. Fielden \& M.J. Davidson (eds.), International Handbook of Women and Small Business Entrepreneurship. Cheltenham: Edward Elgar Publishing Ltd.

OECD Forum (2014). [Online] Received from: https://www.oecd.org/forum/about/ oecd-forum-2014.htm.

Oslo Manual (2005). Guidelines for Collecting and Interpreting Innovation Data. Paris: OECD and Statistical Office of the European Communities.

PARP (2011). Przedsiębiorczość kobiet w Polsce. Warszawa: PARP.

Pocztowski, A. (2008). Zarzqdzanie zasobami ludzkimi. Strategie-procesy-metody. Warszawa: PWE.

Rumińska-Zimny, E. (2004). Women and ICT use in the UNECE region. In: Access to Financing and ICT for Women Entrepreneurs in the UNECE region. 
Challenges and Good Practices. New York and Geneva: United Nations Economic Commission for Europe.

Stevenson, N. (2002). Motywowanie pracowników. Warszawa: Liber.

UNCTAD (2010). Strengthening the Creative Industries for Development in Zambia. United Nations, New York, Geneva.

Wajcman, J. (2010). Feminist theories of technology. Cambridge Journal of Economics, 34(1), 143-152. 


\title{
PKEĆ A INNOWACJE W KRAJACH REGIONU MORZA BAtTYCKIEGO
}

\begin{abstract}
Abstrakt
Tło badań. Artykuł zawiera teoretyczne oraz praktyczne podejście do innowacji w prowadzonych przez kobiety małych i średnich przedsiębiorstwach (MSP).

Cel badań. Praca składa się z dwóch części. W pierwszej części dokonano krytycznego przeglądu literatury dotyczącego płci i innowacji, wskazując, że wymiar płci zwykle nie jest brany pod uwagę. W związku z tym w artykule podjęto próbę zdefiniowania pojęcia innowacji z uwzględnieniem problematyki płci. W drugiej części artykułu zaprezentowano wyniki badań pilotażowych przeprowadzonych wśród posiadanych przez kobiety mikro, małych i średnich przedsiębiorstw w rejonie państw Morza Bałtyckiego.
\end{abstract}

Metodologia. Pytania zawarte w kwestionariuszu ankiety umożliwiły między innymi analizę motywów i barier zakładania firm przez kobiety w branży turystycznej oraz przemysłu twórczego oraz poznanie zakresu innowacji w tych firmach czy dostępności do finansowego i instytucjonalnego wsparcia na poziomie lokalnym i krajowym. Badania przeprowadzono w 2015 roku wśród 102 przedsiębiorczyń z takich państw, jak Estonia, Łotwa, Litwa, Polska i Szwecja.

Kluczowe wnioski. Na podstawie badań można wyciąnać podstawowy wniosek wskazujacy no to, iż we wszystkich badanych państwach nie wykorzystuje się w pełni ekonomicznego oraz innowacyjnego potencjału kobiet. Wyniki badań opisane w artykule ukazuja także, że przedsiębiorstwa reprezentujace sektor kreatywny / usług są bardziej innowacyjne niż te z sektora turystycznego.

Artykuł został opracowany w ramach projektu: Thematic Partnership Winnet Baltic Sea Region Winnet BSR „Gender, Innovation and Sustainable Development in the Baltic Sea Region (BSR)", finansowanego przez Instytut Szwedzki w latach 2013-2016 (www.balticsearegion.org/web/).

Słowa kluczowe: innowacje, innowacyjność, kobiety, płeć, przedsiębiorczość, region Morza Bałtyckiego. 